\title{
Сохранение и реконструкция улиц в исторической части города Гуанчжоу на основе концепции «Здоровый город»
}

\author{
Д.Лысая, Южно-китайский технологический университет, Гуанчжоу, КНР. \\ Ч.Чжан, Южно-китайский технологический университет, Гуанчжоу, КНР.
}

На протяжении 2000 лет Гуанчжоу остаётся центральным портом Южно-Китайского моря и играет важную роль в истории мировой торговли и международного культурного обмена. До наших дней сохранились традиционные (исторические) улицы, заложенные с первых дней основания города до времени правления династий Мин и Цин. Эти улицы представляют собой большую историческую и культурную ценность. Некоторые улицы и переулки нуждаются в модернизации инфраструктуры, а дома, находящиеся на них, - в ремонте. Программы микрореновации предложены в качестве органичного метода восстановления исторически ценной среды. В этой статье в соответствии с концепцией «Здоровый город» исследуются и обобщаются морфологические и пространственные характеристики, такие как зелёные пространства города, многообразия форм традиционных улиц и переулков, стилистика уличной застройки, многофункциональное использование пространства улиц, и подчёркивается необходимость защиты исторической ткани города с применением принципов здорового городского планирования*.

Ключевые слова: Гуанчжоу, характеристики традиционных улиц, концепция «Здоровый город», реновация города.

Renovation of Streets and Lanes in Guangzhou's Historic City Based on the Concept of Healthy City

Lisaia Daria, South China University of Technology, Guangzhou, PRC

Zhang Chunyang, South China University of Technology, Guangzhou, PRC

For 2000 years, Guangzhou has remained the central port of the South China Sea, along with the adjacent territories, it is playing an important role in the history of world trade and international cultural exchange. To this day, the city has retained its traditional streets, laid down from the first days of the city up to the Ming and Qing dynasties. These streets portray local history and culture, preserve the traditions of the healthy lifestyle of the local population. However, some of these streets need renovation. Micro renovation programs are proposed as an organic method for the revitalization of historically valuable environments. This article investigates

* «Исследование адаптивного преобразования города в районе залива Дельта Жемчужной реки на основе городского дизайна» (51778233) выполнено за счет средств Национального фонда естественных наук Китая (National Natural Science Foundation of China: Research on the urban adaptive transformation of the Pearl River Delta Bay Area based on urban design (51778233)) and summaries the morphological and spatial characteristics of street space following the concept of Healthy City. The investigation includes green spaces, the street network, the size of intra-block pedestrian streets, architectural facades street, and the multifunctional use of street space by the residents. Understanding the historical and cultural value of the streets of the historic city is a step toward protecting the morphological characteristics of the traditional street space and promoting the integrated development of a healthy city.

Keywords: Guangzhou, traditional streets characteristics, concept of "Healthy City", urban renewal.

В 2015 году в Пекине была организована третья в истории Нового Китая (с 1949 года) «Центральная городская рабочая конференция» («Zhongyang chengshi gongzuo huiуi»), на которой было принято решение о переходе от экстенсивного к интенсивному освоению городских территорий, проведению реновации районов существующей застройки, сохранению природных ресурсов, защите культурных ценностей и исторического наследия. В 2018 году при посещении общины Юнцин Фан (Yong qing fang) в районе Ливань (Liwan qu) города Гуанчжоу президент Си Цзиньпин рекомендовал в исторических городах проводить программы микрореновации с целью сохранения культурного наследия. Микрореновация помогает сохранить жизнеспособность исторических кварталов путём постепенного возрождения и активизации экономической деятельности без проведения крупномасштабного сноса и перестройки.

В 2020 году города Китая, как и всего мира, столкнулись со значительными изменениями социально-экономической обстановки в связи с распространением пандемии COVID-19. Концепция В03 «Здоровый город» предлагает механизм повышения качества городской среды в интересах здоровья населения, безопасности и удобства общественного пространства. В новых сложившихся условиях при разработке проектов микрореновации городской среды приоритет должен быть отдан в том числе поддержанию физического и психологического здоровья населения.

Гуанчжоу - это современный мегаполис. Исторический центр города насчитывает более 2200 лет, в 1982 году ему присвоен статус «Национальный известный исторический и культурный город». Традиционные ${ }^{1}$ кварталы, улицы

${ }^{1}$ В Китае применительно к историческим кварталам, улицам и зданиям используется прилагательное «традиционные». 
и переулки города являются квинтэссенцией исторической местной культуры и сохраняют уникальную богатую городскую пространственную структуру, а также жилую и торговую атмосферу. Пространственные характеристики традиционных улиц и переулков включают в себя многообразие содержания, эффективное и компактное использование территорий, комфортную и доброжелательную атмосферу.

Исторические улицы Гуанчжоу нуждаются в реализации программ органичной микрореновации и применении устойчивых методов восстановления исторической среды, замене устаревшей инженерной инфраструктуры, создании благоустроенных общественных пространств с целью повышения качества жизни и укрепления здоровья населения. Но проведение этих мероприятий осложняется наличием комплекса вопросов, касающихся прав собственности на недвижимость (в том числе собственников, проживающих за пределами страны), не до конца урегулированным взаимодействием между департаментами защиты культурного наследия и городского планирования, а также связанными с вышеперечисленными аспектами недоработки законодательной базы.

Первостепенной задачей является защита и сохранение уникальной исторически сложившейся ткани города, и затем традиционные кварталы и улицы могут стать объектом городской микрореновации. Комплексное сохранение исторических ландшафтов даёт новый стимул для социально-экономического развития местных сообществ, создания здоровой городской среды и повышения качества жизни населения.

В данной статье исследуются и обобщаются морфологические характеристики традиционных улиц и переулков Гуанчжоу в границах территории «Национальный известный исторический и культурный город Гуанчжоу» ${ }^{2}$ представлена

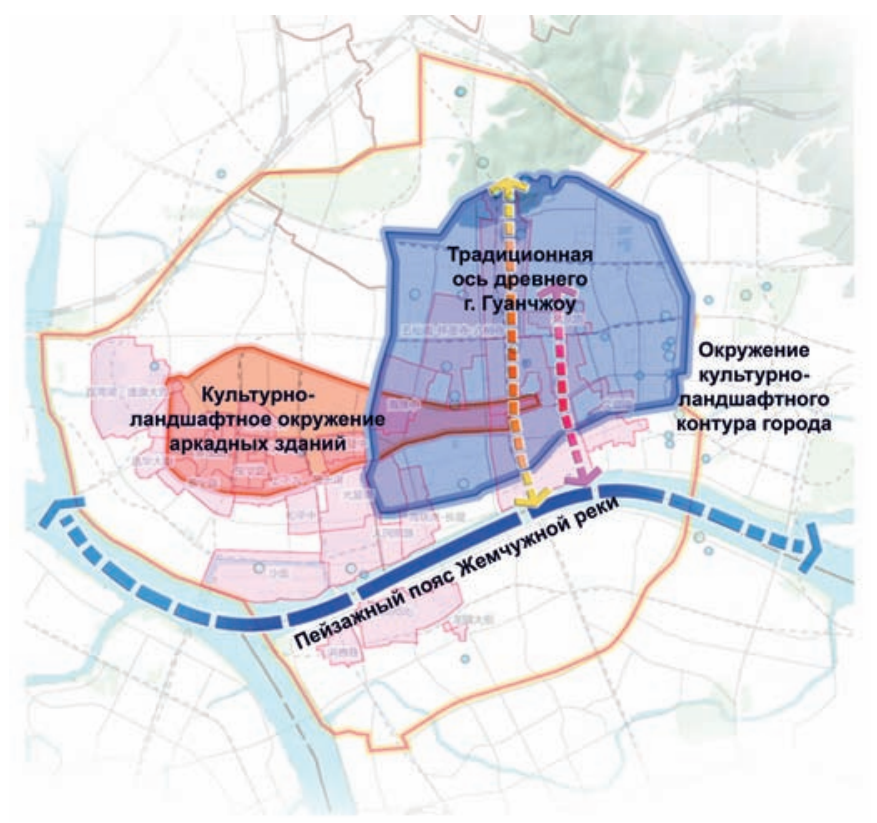

Рис. 1. Комплексная охранная зона историко-культурного города Гуанчжоу (источник: «Генеральный план г. Гуанчжоу 2017-2035 22.») их историческая и культурная ценность, проводится анализ зелёных пространств города, многообразия форм традиционных улиц и переулков, стилистики уличной застройки, многофункциональное использование пространства улиц и подчёркивается необходимость защиты исторической ткани города с применением принципов здорового городского планирования.

\section{Защита и сохранение исторического ландшафта города и традиционных улиц и переулков}

Гуанчжоу - один из древнейших портовых и торговых городов Китая. С него начинался Древний морской шёлковый путь Южно-Китайского моря. Со времени правления династии Тан (618-907) до династии Цин (1644-1912) он проходил более чем через сто стран и регионов и представлял собой крупный морской путь, обеспечивающий торговый и культурный обмен между Китаем и зарубежными странами. В период правления династий Мин и Цин изысканные товары местных ремесленников экспортировались практически на все континенты, что позволило Гуанчжоу стать одним из богатейших городов мира. От правления династии Цин до образования Китайской Народной Республики (1949) районы Ливань (Liwan qu), Юэсю (Yuexiu qu) и Хайчжу (Haizhu qu) были основными центрами городского развития Гуанчжоу с исторической застройкой кварталов Нового времени (1840-1949) и большим количеством древних культурных памятников.

Ниже приведены законы КНР, подзаконные и нормативные документы, обеспечивающие и регулирующие сохранение исторических городских ландшафтов, комплексное сохранение исторической структуры города, исторических особенностей, пространственного масштаба и исторического наследия, а также градостроительное развитие:

- Закон Китайской Народной Республики об охране культурных реликвий 1982 года, пересмотрен в 2017 году;

- «План сохранения известного исторического и культурного города Гуанчжоу» в 2003 году одобрен Правительством Гуанчжоу, в настоящее время пересматривается с учётом задач нового этапа развития города;

- «Генеральный план г. Гуанчжоу 2017-2035 гг.» (2017);

- «Генеральный план реновации г. Гуанчжоу 2015-2020 гг.» (2017);

- «Положение об охране известного историко-культурного города Гуанчжоу», (1998), пересмотрено в 2015 году.

Статус «Национальный известный исторический и культурный город Гуанчжоу», (рис. 1) распространяется на районы Ливань, Юэсю и Хайчжу, ограниченные участками улиц: Дунхао Юн (Donghao Yong) - Сяобэй Лу (Xiaobei Lu) - Хyаньшичжун Лу (Huanshizhong Lu) - Хуаньшиси Лу (Huanshixi Lu) - Жэньминьбэй Лу (Renminbei Lu) - Люхуа Лу (Liuhua Lu) - Гуансаньте Лу (Guangsantie Lu) - Река Чжуцзян от улицы Чжуцзян Дацяо Дунцяо до улицы Хайпанней Цзе (Zhujiang -

\footnotetext{
2 Город Гуанчжоу в границах до 1949 года - площадь 20,39 кв. км, население - 1,614 млн чел., плотность населения - 791,81 чел./га [1]

${ }^{3}$ В статье приведены современные названия улиц.
} 
Zhujiang Daqiao Dongqiao - Haipangnei Jie) - Хайпанней Цзе (Haipangnei Jie) - Синьминь Дацзе (Xinmin Dajie) - Гэсинь Лу (Gexin Lu) - Мэйюаньси Лу (Meiyuanxi Lu) - Гун'е Дадао Бэй (Gongye Dadao Bei) - Наньтянь Лу (Nantian Lu) - Цзянвань Лу (Jiangwan Lu) - Цзянвань Дацяо (Jiangwan Daqiao).

До наших дней сохранились улицы, заложенные во времена основания города - Бэйцзин Лу (Beijing Lu) и до правления династий Мин и Цин - Чжуншань Лу (Zhongshan Lu), Цзэфан Лу (Jiefang Lu), Сяобэй Лу (Xiaobei Lu), Цанбянь Лу (Cangbian Lu), Дэчжэн Лу (Dezheng Lu) и др. В «Плане сохранения известного исторического и культурного города Гуанчжоу» указано, что 354 исторические улицы (в том числе улицы аркадного типа) находятся под защитой городских властей. Некоторые из них повреждены и нуждаются в восстановлении.

\section{Реновация и микрореновация городской среды}

Гуанчжоу находится в авангарде программ городского развития и реконструкции. Научные исследования направлены на поиск путей социально-экономического возрождения исторических улиц при сохранении их ценной исторической среды. Данное исследование преемственно развивает направление трудов академика Хэ Цзинтана [2], который отмечает, что в проектах реновации необходимо применять ориентированную на людей градостроительную концепцию и удовлетворять растущий спрос на лучшую жизнь; сохранять исторический облик зданий, целостность исторический среды и развивать принципы, формы и приёмы традиционной архитектуры за счёт инновационных решений, которые должны отражать гармоничное единство региональных и культурных особенностей.

Сунь Иминь [3] полагает, что в Китае за последние сорок лет было построено городское и общественное пространство, но главное - создать жизненное пространство, которое учитывает различные взаимосвязи и исторические трансформации.

Ранее в публикации [4] отмечалось, что в китайских городах при большой численности населения и ограниченных земельных ресурсах, система общественных открытых пространств должна органично сочетаться с компактной и интенсивной городской застройкой, в сочетании со смешанного типа функ- циями землепользования. Общественные пространства, оптимизированные для пешеходной доступности, играют важную роль в стимулировании активного образа жизни населения. Их дизайн должен быть ориентирован на потребности населения.

Как и природные ресурсы, ресурсы культурного наследия ограничены [5]. Это важно учитывать в практике городского планирования.

В Китае на исторически значимых городских территориях применение микрореновации осуществляется методом реконструкции исторических зданий и общественных территорий путём восстановления, частичного сноса и строительства новых зданий на месте утраченных. Реконструкция осуществляется в соответствии с принципом «реконструировать старое как старое и строить новое, как прежде» [6].

Программы микрореновации городской среды могут способствовать формированию городской среды, благоприятствующей здоровому образу жизни и физической активности населения. Желательно учитывать такие показатели, как пешеходная доступность, степень проницаемости уличной сети, количество перекрёстков и размер кварталов, доступность для пожилых людей и людей с ограниченными возможностями, качество тротуарного покрытия, безопасность, наличие разнообразных и интересных мест для посещения и визуального впечатления.

\section{Характеристики традиционных улиц}

Зелёные пространства исторического города

Территорию, выбранную для основания древнего города, можно описать так: «позади гора, впереди море; здесь встречаются река и море» [7]. Планировочной композиции города присущ порядок организации гуманистического пространства в тесной связи с природным окружением, где главными элементами являются гора на севере и река на юге (рис. 2). Древние китайские учения рассматривают «целостность» силы природы и объединяют природу с жизненным пространством людей [8].

В древних китайских городах было несколько типов мест с атрибутами общественного пространства, отличающихся от западных. Зелёные территории древнего города включали
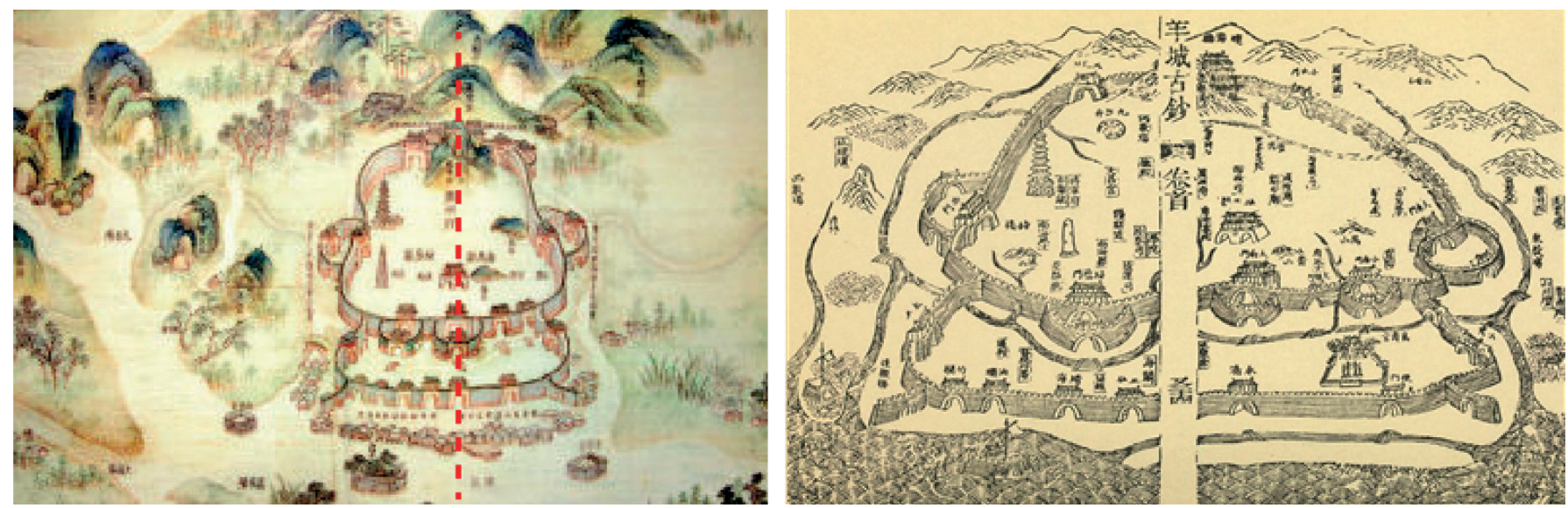

Рис. 2. Традиционная ось города Гуанчжоу, сформированная по принципу «позади гора, впереди море; здесь встречаются река и море» 

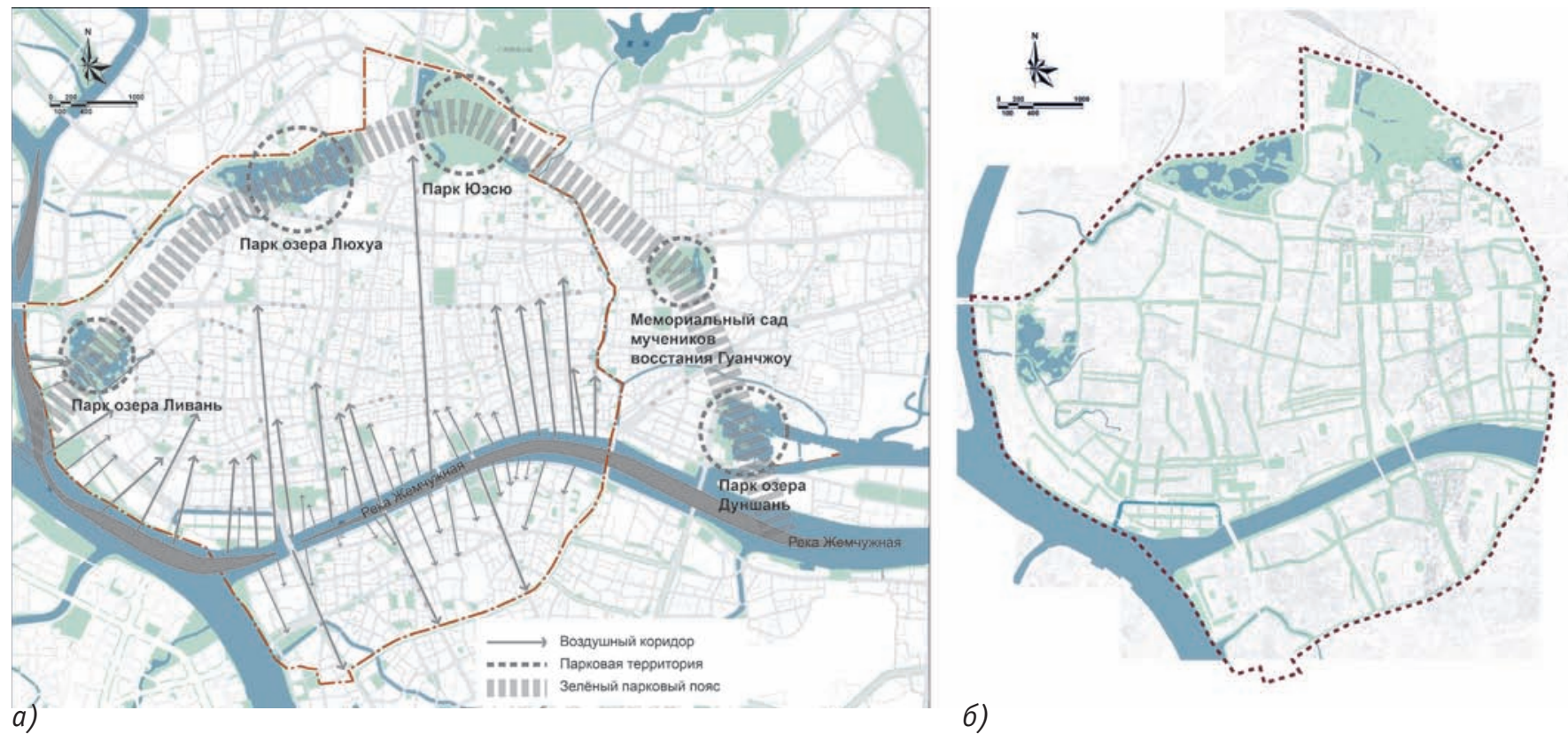

б)

Рис. 3. Зелёные территории исторического города Гуанчжоу: а) природное окружение исторического города: зелёный парковый пояс и река Жемчужная; б) зелёные пространства внутри исторического города

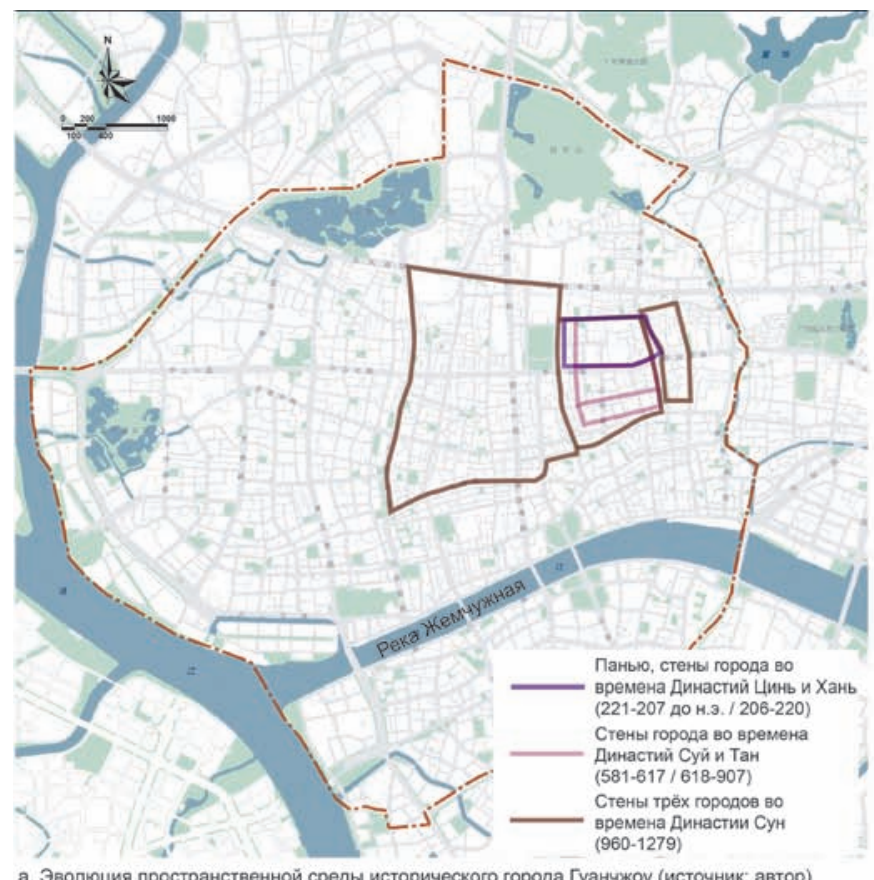

а. Эволюция пространственной среды исторического города Гуанчжоу (источник: автор)

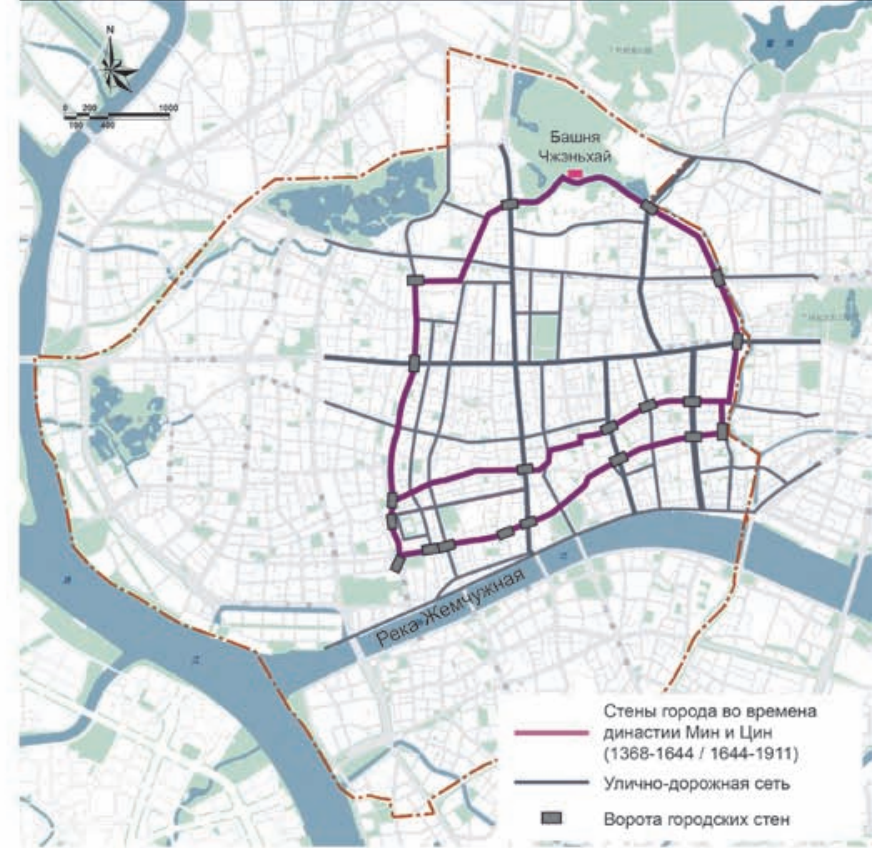

б. Улично-дорожная сеть внутри городских стен во времмена равления Династии Цин (источник: автор)

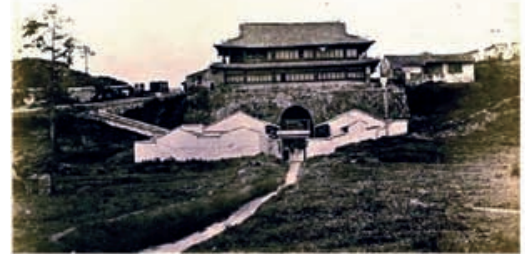

в. Главные северные ворота, 1860 (source: https://kknews. oc/)

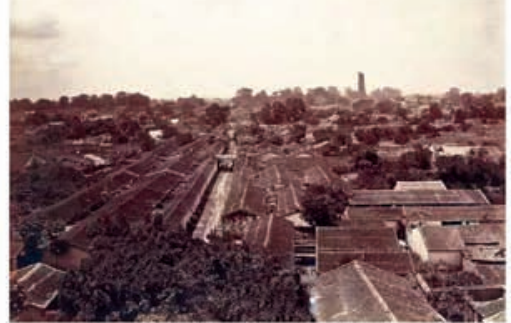

г. Цветочная пагода, окружённая малоэтажной застройкой, поздняя династия Цин (source: https://3g.163.com/)

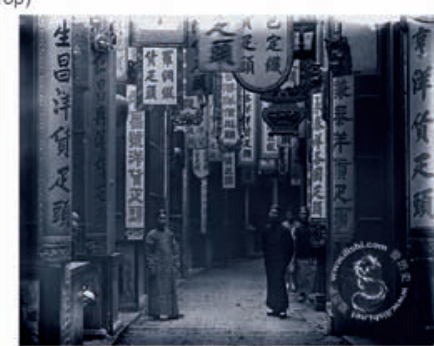

д. Янхаоитяо Цзе (Yanghuo yitiao jie), поздняя династия Цин (source: www lishi.net)

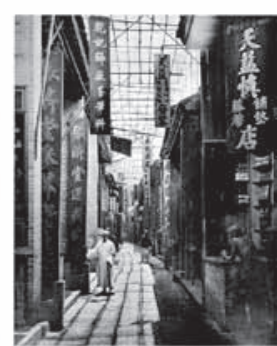

е. Торговая улица, 1873

Рис. 4. Эволюция планировочной структуры традиционных улиц Гуанчжоу 
в себя небольшие сады правительственных и различных, административных учреждений, религиозных сооружений (родовых клановых храмов, монастырей, даосских и конфуцианских храмов), частные сады. В XX веке под влиянием западных течений во время модернизации городов были заложены многие городские общественные парки [9].

В Гуанчжоу в XX веке вокруг исторического города сформировался зелёный пояс из пяти парков: парк озера Ливань (Liwan Lake Park), парк озера Люхуа (Liuhuahu Park), Парк Юэсю (Yuexiu Park), Мемориальный сад мучеников восстания Гуанчжоу (Guangzhou Uprising Martyrs Park), парк озера Дуншань (Dongshan Lake Park) (рис. 3). Внутри исторического города основные зелёные территории - это Народный парк (Renmin Park), площадь Хайчжу (Haizhu square), зелёные бульвары, а также набережная реки Жемчужной, общая длина которой на территории старого города, расположенного по обе стороны реки, составляет 11,5 км. Внутри жилых кварталов из-за высокой плотности застройки зелёных территорий меньше. Местные жители возле своих домов любят выставлять в кадках небольшие деревья и цветы, которые придают особый шарм старым улочкам.

Согласно статистическим данным, доля зелёных насаждений в районе Ливань составляет 8,14\%, а уровень зелёного покрытия - 15,0\%; общая площадь общественных зелёных территорий составляет 62,79 га, на душу населения приходится 1,22 кв.м. Доля зелёных насаждений в районе Юэсю выше и достигает $21 \%$, а уровень зелёного покрытия составляет 27,0\%; общая площадь общественных зелёных территорий составляет 164,57 га, на душу населения приходится 3,8 кв.м [7].

Структура улиц и городская ткань исторического города Гуанчжоу

Исторический город Гуанчжоу имеет нерегулярную форму, обращённую на юг к морю и Жемчужной реке, его улицы ориентированы по сторонам света с юга на север и с востока на запад. Структура улиц делится на пять типов [7], описанных ниже.

Структура улиц внутри городской стены Гуанчжоу, сформированная во времена династий Мин и Цин

Во времена династий Мин и Цин структура улиц (рис. 4 б) сложилась под влиянием эволюции древних городов разных периодов (см. рис. 4 а) и типичной уличной системы китайского города, укреплённого городскими стенами. Старейшие улицы исторического города были проложены также на месте укреплённых стен древних городов (рис. 4). Внутри городской стены улицы делились на главные и второстепенные. Главные улицы соединяли ворота города в направлении юг-север и запад-восток. В городе процветала торговля, поэтому по обеим сторонам улиц располагались торговые лавки. Вплоть до конца XIX века улицы сохраняли средневековую структуру и оставались узкими и неровными.

Со второй половины XIX века, после окончания Опиумных войн, в городском строительстве начинает ощущаться влияние стиля Британской колониальной архитектуры. Постепенно внедряются новые западные строительные технологии, материалы и конструкции, появляются первые здания аркадного типа (Qilou) ${ }^{4}$.

Сеть дорог, построенная на месте снесённых городских стен во времена Китайской Республики

После Синхайской революции 1911 года началась новая эра модернизации и строительства города. В октябре 1918 года был основан Муниципальный офис города Гуанчжоу и выпущено Заявление № 1, которое для улучшения дорожного движения предписывало снести городские стены и на их фундаментах построить дороги (рис. 5) [10]. В середине 1920 х годов были проведены масштабные работы по расширению основных дорог. В этот период Гуанчжоу становится одним из ведущих центров городского развития в Китае.

15 февраля 1921 года было учреждено муниципальное правительство Китая - мэрия Гуанчжоу, и Гуанчжоу первым в Китае официально получил статус города. В это время при строительстве новых дорог и улиц активно применялся опыт

4 В 1912 году был выпущен документ «Строительные нормы и правила», где впервые официально применился термин «здание аркадного типа».

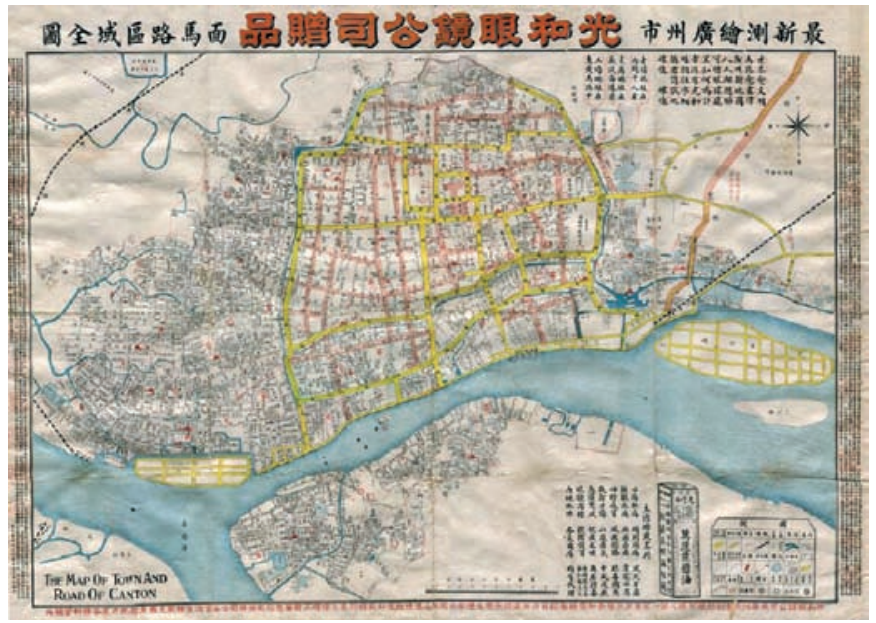

a)

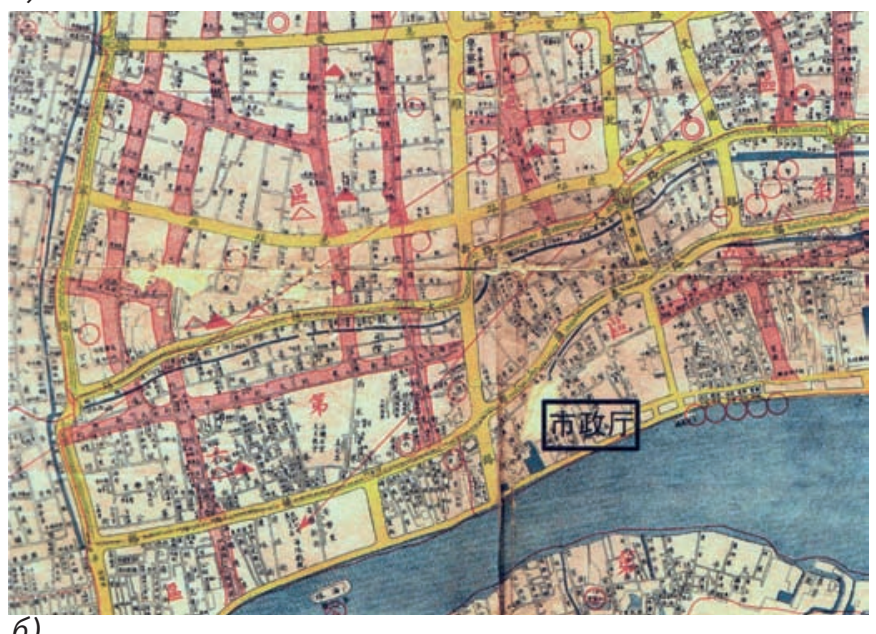
б)

Puс. 5. Карта улично-дорожной сети Гуанчжоу. Начало 1920-х годов: а) карта города; б) увеличенный фрагмент карты 


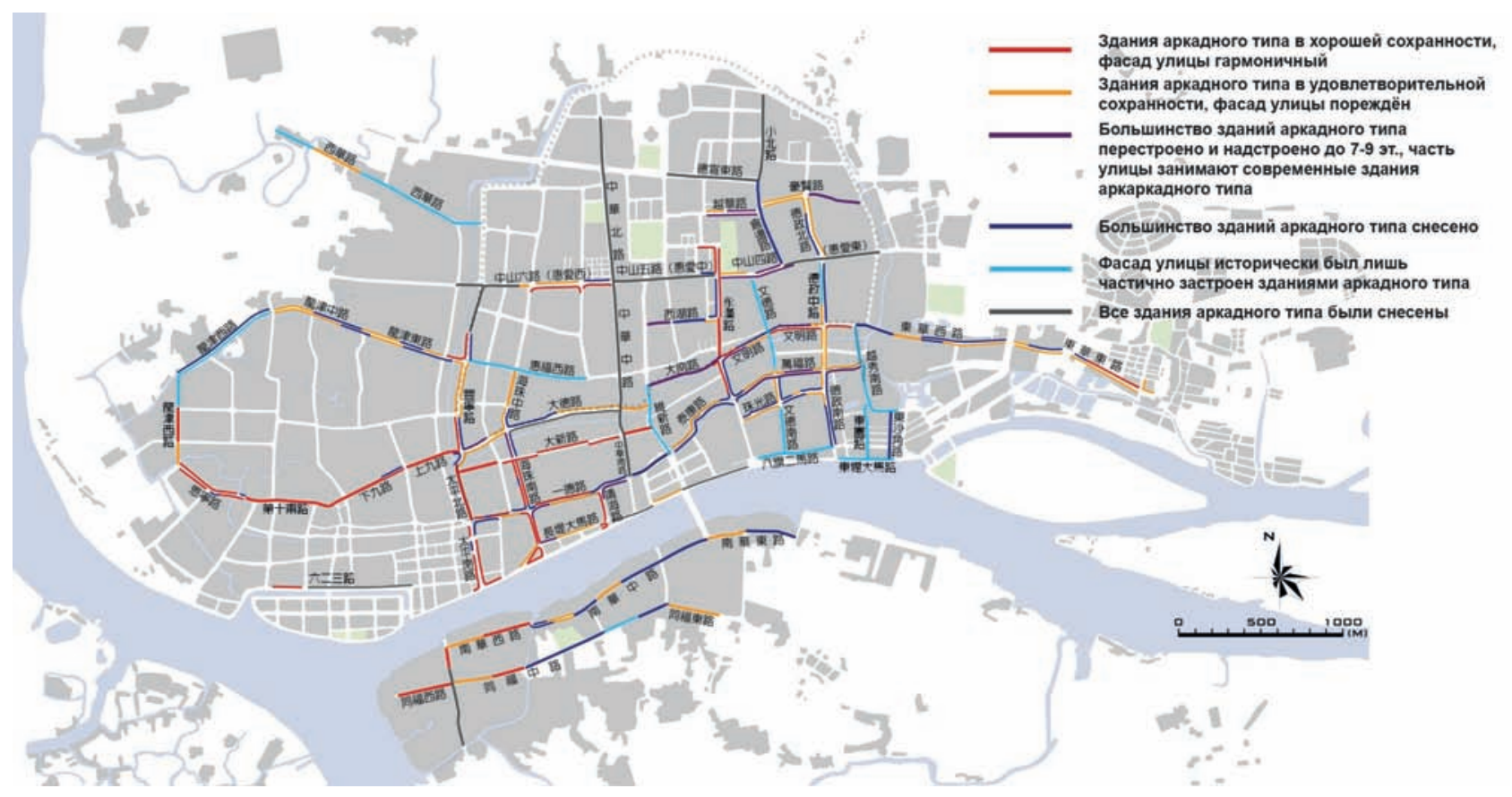

Puс. 6. Карта расположения улиц аркадного типа в Гуанчжоу. 2014 год (изображение из открытых источников сети Интернет)

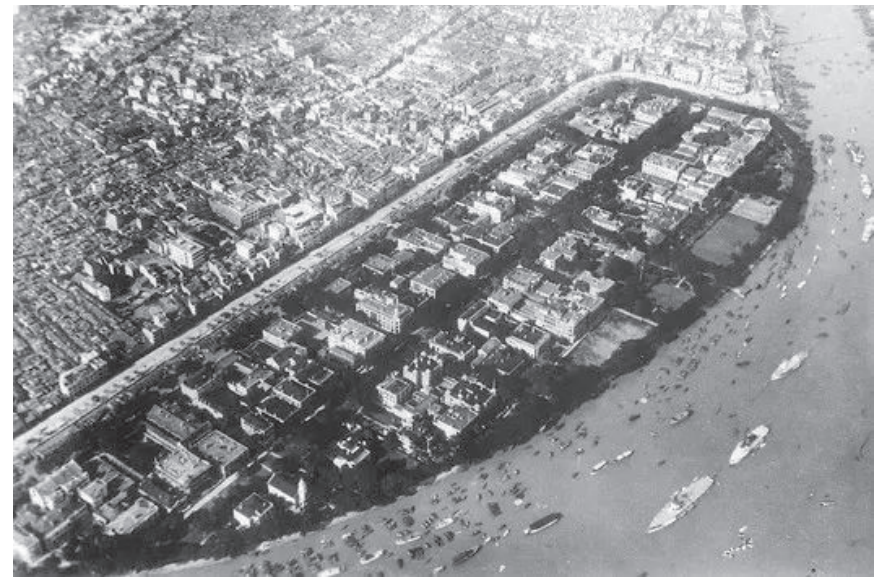

a)

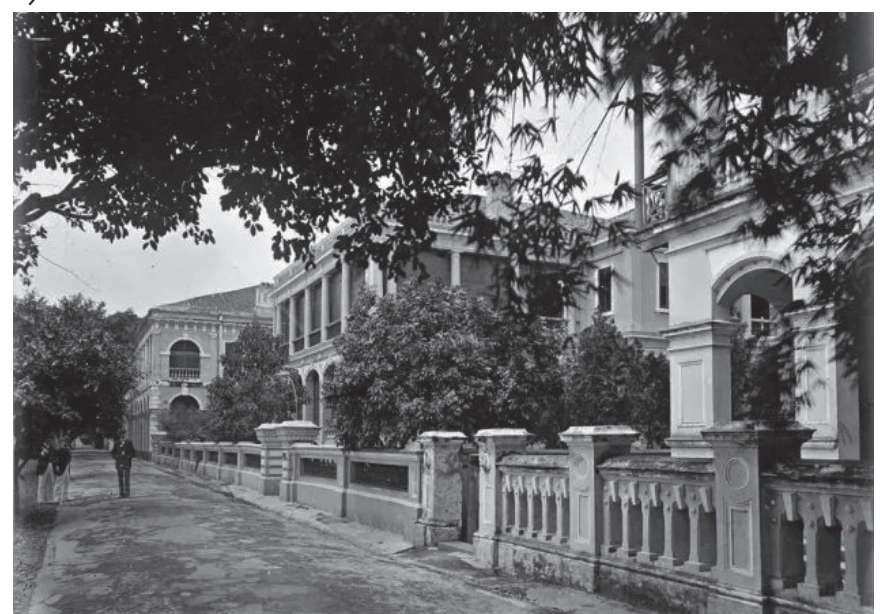

б)

Рис. 7. Планировка улиц на острове Шамянь. а) аэрофотосъёмка острова Шамянь в период Китайской Республики; б) остров Шамянь в 1883 году (фото из открытых источников сети Интернет) американского градостроительства. Муниципалитет поощрял строительство вдоль улиц зданий аркадного типа. Для этого были разработаны регламенты, которые устанавливали ширину дорог, выделяли пространство по обеим сторонам дороги для строительства аркад, устанавливали их глубину и высоту. Здания аркадного типа представляют собой синтез китайской планировочной структуры с фасадами в западном стиле (рис. 6). Улицы аркадного типа позволяли максимально использовать уличное пространство и создавали комфортную среду в условиях местного субтропического климата (высокая температура, обильные тропические дожди, высокая влажность воздуха). С конца 1920-х - начала 1930-х годов в Гуанчжоу было построено около 40 км аркадных улиц, где располагались более 20000 магазинов. В среднем, на 50 жителей Гуанчжоу приходился один магазин. Современные 4-я, 5-я и 6-я дороги Чжуншань - это первые коммерческие районы Гуанчжоу [11].

\section{Регулярная сетка дорог периода Нового времени}

В 1930-х годах в Гуанчжоу были разработаны единые планировочные стандарты и генеральный план города. Применялись новые методы городского планирования, расширялись старые улицы и прокладывались новые дороги. Регулярные системы улично-дорожной сети были в основном сосредоточены в двух районах города - Сигуань и Шамянь (рис. 7) [9; 12].

Сеть дорог, относящаяся к исторической водной системе каналов

Во времена правления династии Сун в городе была заложена дренажная система из шести каналов (рис. 8 а), которые соединялись с Жемчужной рекой и спасали город от наводнений и пожаров. Их ширина достигала 15 м, что позволяло 
местным жителям использовать каналы как транспортные артерии [13]. Система каналов функционировала до 1950-х годов, затем их перекрыли и по ним проложили дороги. В Гуанчжоу городской ландшафт был сформирован с учетом естественной, живописной и обширной речной системой реки Жемчужной. Система водных каналов внутри города влияла на образ жизни местного населения и создавала благоприятную прохладную среду в жаркие летние дни. В настоящее время мы можем наслаждаться лишь небольшими сохранившимися фрагментами водных городских пейзажей (рис. 8 б, в).

\section{Традиционная ось города}

Со времён династии Цин в Гуанчжоу постепенно формировалась традиционная центральная ось города, которая имеет важное историческое и культурное значение. На этой оси расположены башня Чжэньхай (на вершине горы Юэсю, самой высокой точке древнего Гуанчжоу), памятник Сунь Ятсену, мемориальный зал Сунь Ятсена, Народный парк и площадь Хайчжу (рис. 9).

\section{Плотность улично-дорожной сети}

Городские кварталы, построенные до массовой автомобилизации XX-го века, в основном, сформированы компактной малоэтажной застройкой, кварталами небольшого размера, привлекательными для пешеходов и велосипедистов. Сравнительный анализ ткани исторически сложившихся кварталов Парижа, Лондона, Нью-Йорка и Гуанчжоу на участках размером 1 кв.км (рис. 10), показал, что Гуанчжоу обладает плотной сеткой улиц и перекрёстков, превышая по данным показателям Париж и Нью-Йорк, уступая только Лондону. Из-за наличия множества тупиков сеть традиционных улиц и переулков Гуанчжоу не всегда обладает хорошей проницаемостью и не очень чётко читается.

\section{0бзор ширины улиц исторического квартала}

Классификация улично-дорожной сети в историческом центре делится на два типа: транспортные артерии - дороги (Lu) и внутриквартальные пешеходные улицы (Jie), переулки (Xiang) и узкие улочки (Li).

Для исследования авторы выбрали квартал Гуанчжоу, прилегающий к юго-восточной стороне площади Хайчжу, окружённой памятниками культуры - свидетелями многовековой истории города. По периметру квартал окружён дорогами, пешеходная часть которых формируется зданиями аркадного типа: Ции Лу (Qiyi Lu), Данань Лу (Danan Lu), Бэйцзин Лу (Beijing Lu) и Тайкан Лу (Taikang Lu) (рис. 11). Ширина проезжей части дорог варьируется от 15 до 24 м, ширина пешеходной аркады составляет 3,5-4 м. Здания аркадного типа хорошо сохранились. Внутри кварталов все улицы пешеходные, лишь некоторые участки доступны для проезда автомобилей и имеют парковочные места. Пространство внутриквартальных улиц нуждается в проведении ремонтных работ.

Улица Гаоди Лу (Gaodi Lu) соединяет дороги Бэйцзин Лу на востоке и Ции Лу на западе. Она является одной из старейших коммерческих улиц, сохраняющей память о местной истории и архитектуре Линнань. Эта оживлённая торговая улица является центральной в структуре квартала. Её ширина доходит

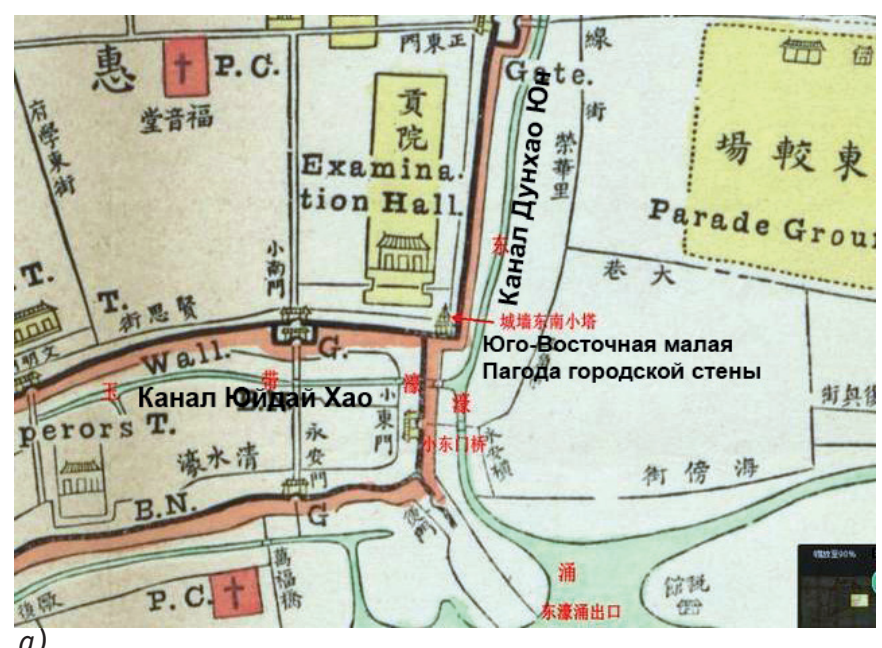

a)
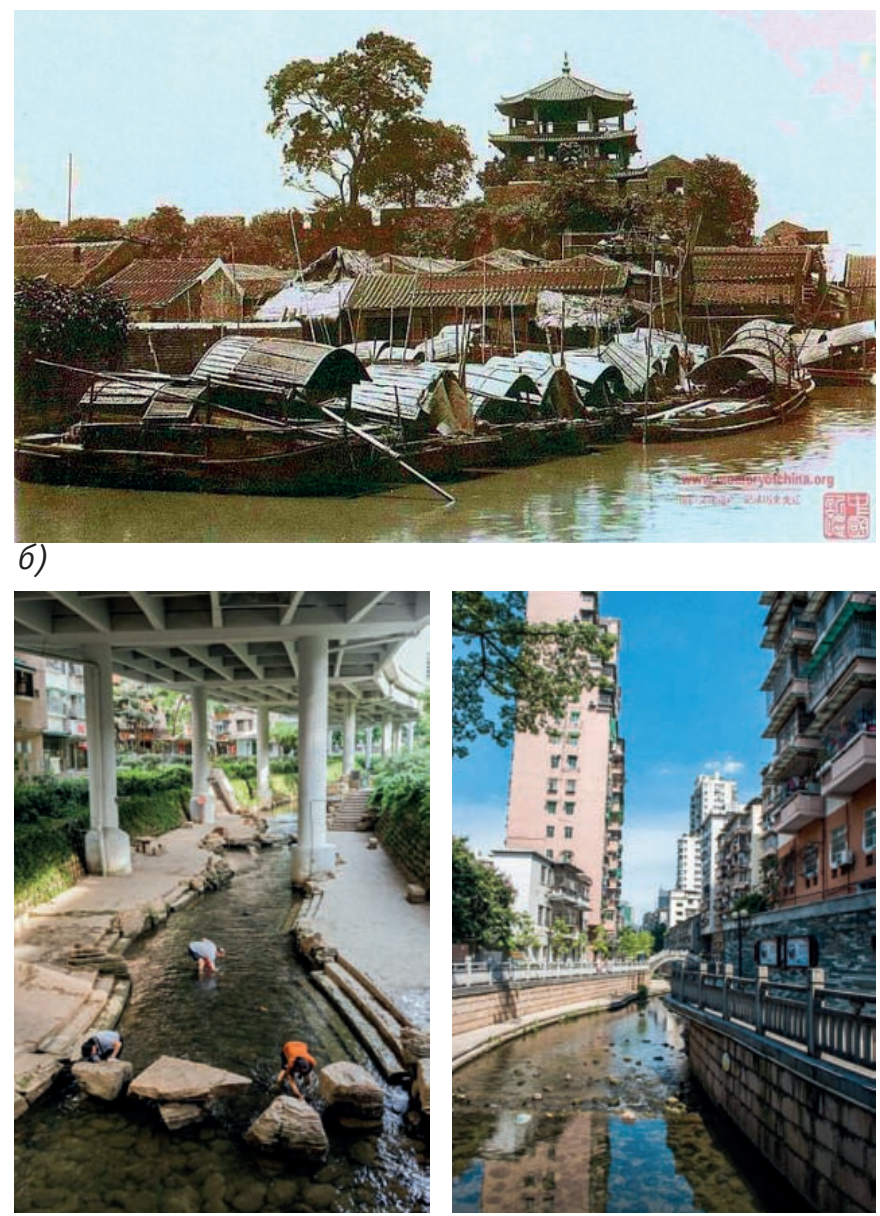

B)

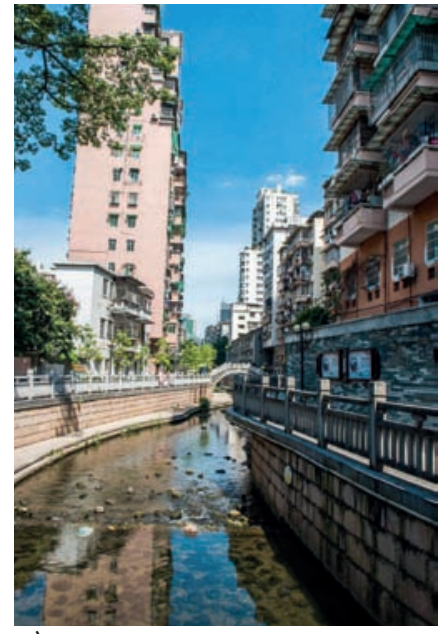

2)

Pис. 8. Система водных каналов внутри исторического города: а) юго-восточная часть Гуанчжоу, фрагмент карты 1890 года; б) канал Дунхао Юн (Donghao Yong) и трёхярусная восьмиугольная пагода у юго-восточной городской стены (источник: https://kknews.cc/zh-sg/history/9z54yyb.html); в, г) канал Дунхао Юн после реконструкции 2010-х годов. Фото 2020 года. Фото из открытых источников сети Интернет 
до 8 м, по обеим сторонам расположены трёхэтажные здания, первые этажи занимают торговые лавки, на верхних этажах расположены жилые помещения и офисы. Второй по важности является Мупайсинь Лу (Mupaixin Jie) - это жилая улица, центр местного сообщества, на которой расположены отдельные продуктовые лавки и небольшой уличный продуктовый рынок. Улица Юйдай Хао (Yudai Hao) - это перекрытый бетонными плитами исторический водный канал - в настоящее время жилая улица с фрагментами уличной торговли, мало оживлённая и разделённая на два участка современным зданием отеля. Помимо трёх улиц здесь расположено бессчётное количество переулков, шириной 3-5 м, которые обеспечивают доступ к жилым домам и складам, а также внутренних улочек, шириной 1-3 м, которые связывают между собой улицы и переулки. В квартале сохранились исторические здания поздней династии Цин и Китайской Республики. Покрытие улиц различное: на многих улицах - сохранившаяся со времён динации Цин крупноблочная каменная кладка, современная

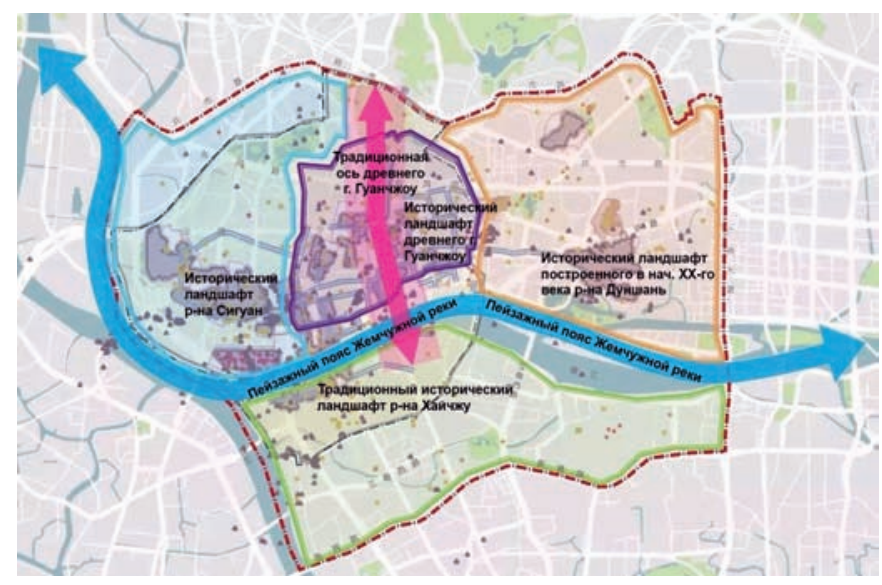

Pис. 9. Общая структура исторического центра Гуанчжоу с обозначением традиционной оси (источник: «Генеральный план г. Гуанчжоу 2017-2035 г2.»)

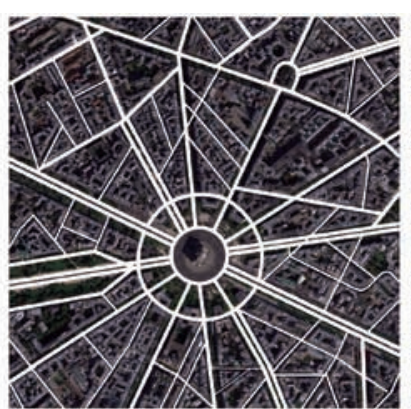

ПАРИЖ

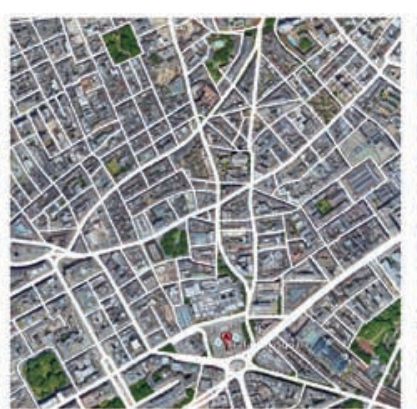

лондон гранитная плитка, тротуарная плитка, на улице Юйдай Хао канал покрыт бетонными плитами. Квартал имеет плотную застройку высотой 2-10 этажей. По периметру квартала на трёх перекрёстках построены высотные здания.

Квартал связан с востока на запад улицей Гаоди Лу, но не имеет связи с юга на север. Улучшение связности улиц положительно повлияет на пешеходную доступность, увеличит площадь и пропускную способность пешеходных улиц, сократит время пути.

\section{Специфика уличных фасадов}

На фасадах зданий традиционных улиц присутствуют декоративные элементы китайской и западной архитектуры (рис. 12). В Гуанчжоу исторически фронтальная часть улиц формировалась сплошными фасадами жилых и коммерческих зданий. Коммерческие помещения отданы для малого и среднего бизнеса в области розничной торговли, общественного питания и сферы обслуживания. Они могут быть полностью открыты либо иметь широкое фасадное остекление, что стирает границы между частным и общественным пространствами. Утром, когда хозяева открывают двери своих магазинов или ресторанчиков, улицы превращаются в оживлённый рынок.

В 2000-е годы на многих традиционных улицах здания аркадного типа были утрачены, на некоторых улицах сохранились лишь фрагменты старой застройки. Необходимо, по возможности, восстановить утраченные здания аркадного типа и воссоздать стилевое единство исторического облика улиц.

\section{Оживлённые и многофункциональные улицы Гуанчжоу}

Исторические кварталы сформированны застройкой смешаного типа, где жилые функции соседствуют с коммерческими (оптовые рынки, ресторанчики с местной известной во всём мире кантонской кухней, магазины с произведениями местного искусства, антикварные лавки, отели и др.). Благодаря жаркому климату улицы Гуанчжоу круглый год представляют собой жи-

\begin{tabular}{lccc}
\hline $\begin{array}{l}\text { Количество } \\
\text { перекрёстков } \\
\text { на км² }\end{array}$ & 114 & 260 & 64 \\
$\begin{array}{l}\text { Среднее } \\
\text { растояние между } \\
\text { перекрёстками (м) }\end{array}$ & $50-160$ & $25-100$ & $80-274$ \\
\hline
\end{tabular}

Рис. 10. Сравнительный анализ плотности дорожно-уличной сети и перекрестков Парижа, Лондона, Нью-Йорка и Гуанчжоу. Площадь исследуемых участков - 1 кв. км. Схема авторов статьи 
вописные и многофункциональные общественные пространства и являются зоной, где проявляется социальная активность местного сообщества. Жители используют улицы для торговли и совершения покупок, встреч и общения, для утренней зарядки,
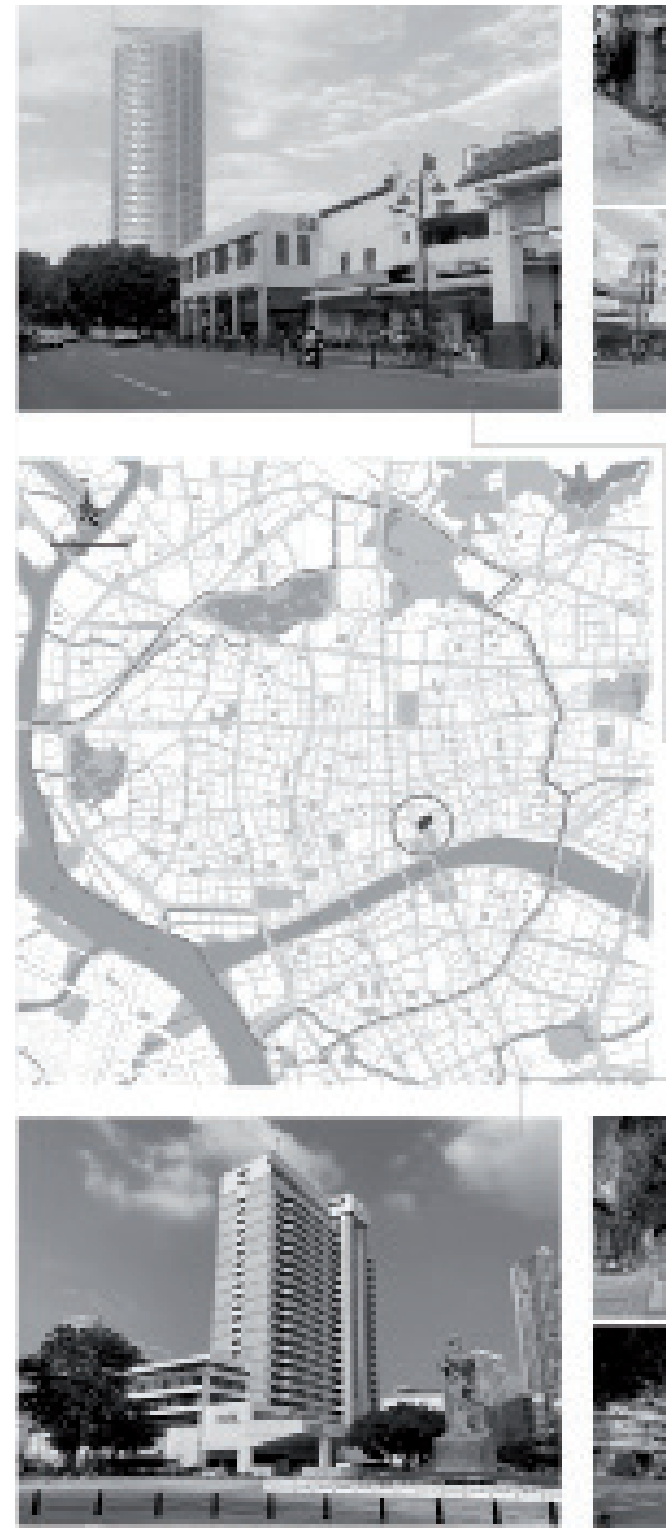
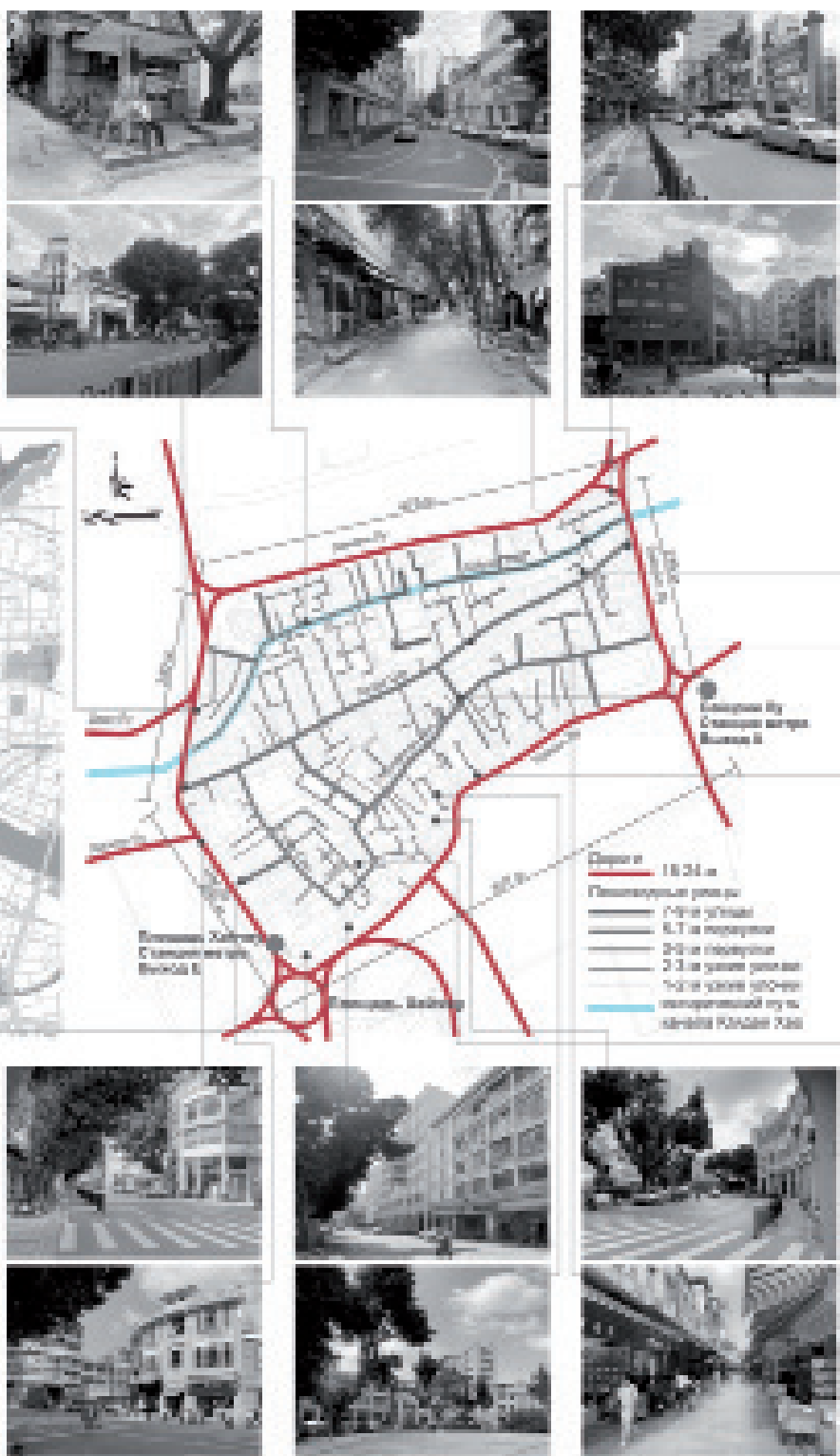
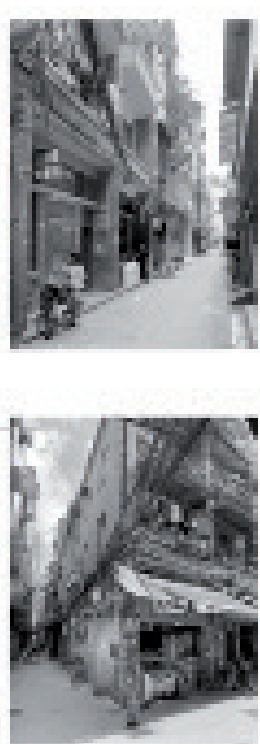

Рис. 11. Классификация и ширина улицулично-дорожной сети квартала примыкающего кплощади Хайчжу. Схема авторов статьи

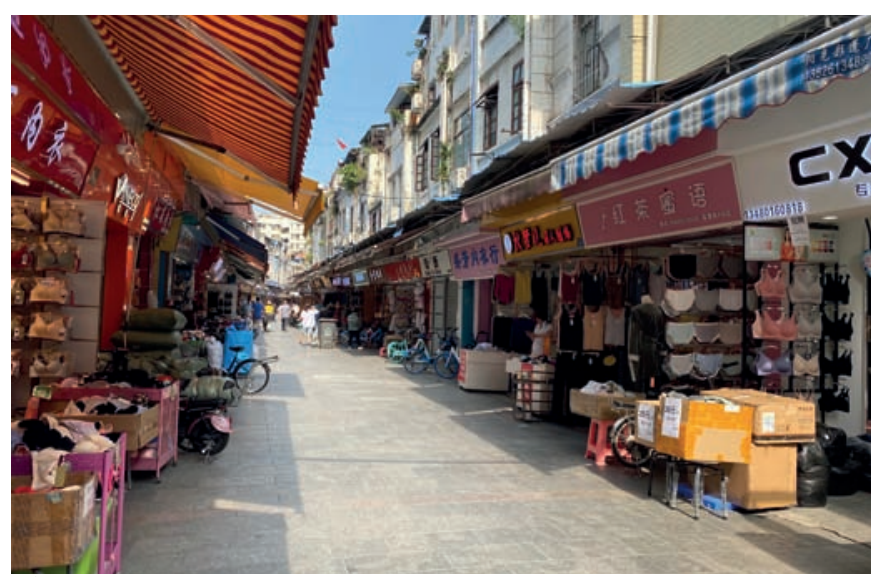

a)

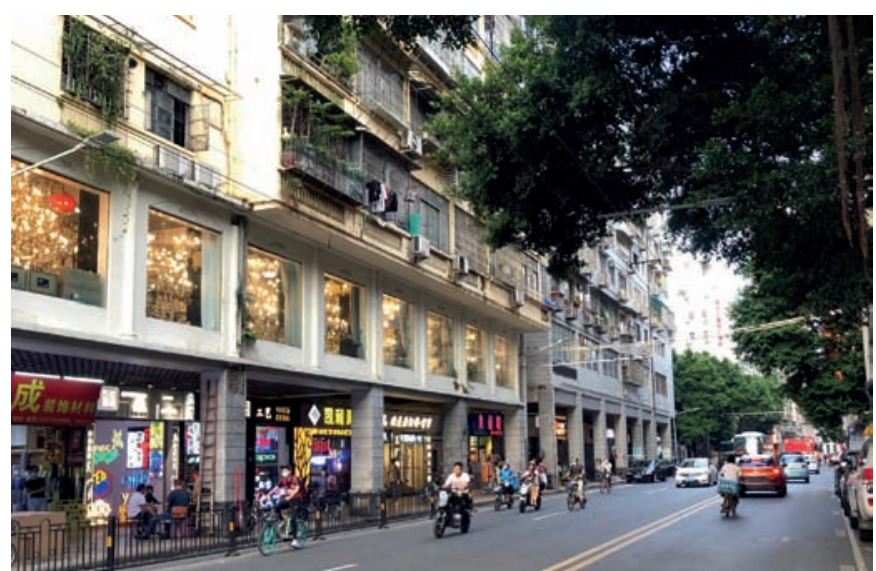

б)

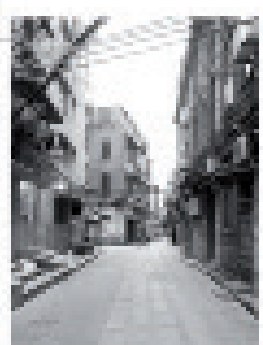

Рис. 12. Фасады традиционныхулиц Гуанчжоу: а) внутриквартальная улица Гаоди Лу; б) улица (дорога) аркадного типа Данань Лу 
танцев, музыкальных выступлений, косметических процедур, отдыха, сушки белья и др. Сохранение и возрождение местных культурных традиций имеет важное значение для поддержания социального и психологического здоровья жителей.

\section{Заключение}

Формирование древней планировочной структуры города основывалось на восприятии «целостности природы»: слияния гуманистического пространства и природного окружения через ось от горы Юесю до реки Жемчужная. Сомасштабность человеку, компактность, густая сеть удобных для пешеходов улиц, зелёный парковый пояс вокруг исторического центра, улицы аркадного типа, система рек и каналов - всё это в совокупности создаёт приятную городскую среду, адаптированную к местному жаркому климату. Сложившаяся пространственная структура города должна быть сохранена. Создание здорового уличного пространства возможно при комплексном и системном подходе к возрождению экосистемы города, его историко-культурных ценностей и традиций, а также формировании новой культуры, основанной на преемственности важнейших культурных координат общества.

Богатая история Гуанчжоу отразилась в пространственных и стилистических характеристиках исторических улиц, впитавших в себя влияния различных культур и обладающих особым колоритом и шармом.

Исторический город - это очень хрупкая система, которую легко разрушить. Поэтому программам реновации должны предшествовать глубокое изучение и анализ исторической застройки и эффективная комплексная защита исторического ландшафта и культурного наследия.

Плотность дорог и внутриквартальных улиц в историческом городе очень высока. Проведённое исследование показало, что многие кварталы имеют вытянутые формы, и для удобства пешеходов в них желательно соединить продольные главные улицы в центральной части кварталов путём создания новых улиц при минимальном влиянии на историческую застройку. Авторы считают, что данный вопрос требует более глубокого изучения, чтобы не причинить урон исторической застройке.

Фасады улиц, опоясывающих кварталы, в основном формируются зданиями аркадного типа, которые сочетают в себе коммерческие и жилые функции. Они создают наиболее благоприятную среду для пешеходных прогулок и проведения свободного времени на улицах в любое время года. Авторы считают, что тенденция строительства аркадных улиц должна продолжаться и необходимо искать новые стилистические решения для данного типа зданий, тем самым сохранить традиционные ценности и разнообразить облик исторических улиц.

Исторический центр Гуанчжоу представляет собой не только историческую и культурную ценность, но и является носителем здорового образа жизни местных жителей. Защита пространственных характеристик традиционных улиц и переулков - важный аспект здорового развития города.
Необходимо отремонтировать и восстановить разрушенные фрагменты улиц, провести оптимизацию уличного пространства путём сноса ветхих строений и за счёт этого увеличить общественные и зелёные территории внутри кварталов, учесть интересы местных жителей и сделать приоритетом сохранение традиционного образа жизни. Исходя из вышеперечисленных приоритетов необходимо разработать программы микрореновации таким образом, чтобы улучшение качества жизни населения было достигнуто в условиях сохранения исторического наследия. В этом случае веками накопленные богатые исторические и культурные ресурсы станут источником социально-экономического развития местных сообществ.

\section{Лumepamypa}

1. 《广州市城市体规划 1991-2010》

2. 何镜堂. 城市更新中的建筑创作. 中国城市更新发展 报告 2018-2019. / 镜堂何. - 北京: 中国城市科学研究会, 2019. - C. 2-8.

3. 孙一民. 城市公共空间品质营建. 中国城市更新发 展报告 2018-2019. / 一民孙. - 北京: 中国城市科学研 究会, 2019. - C. 21-25.

4. 张春阳. 基于健康促进理念的城市设计思考. [Электронный ресурс] / 阳张春 // 健康城市实验室 WLANLab. 10.03.2020. - Режим доступа: https://mp.weixin.qq.com/s/ RAFqj5oSv-1bpsA2DdI1_w (дата обращения: 10.11.2020).

5. Шевченко, Э.А. Градостроительные проблемы сохранения историко-культурного ресурса России [Электронный ресурс] / Э.А.Шевченко // Academia. Архитектура и строительство. - 2012. - №1. - Режим доступа: https://cyberleninka. ru/article/n/gradostroitelnye-problemy-sohraneniya-istorikokulturnogo-resursa-rossii (дата обращения: 16.02.2021).

6. 赵晓铭. 广州旧城区公共绿化空间微改造探析一以 昌华涌为例. [Электронный ресурс] / 铭赵晓 // 第一论文 网. - 26.10.2015. - Режим доступа: https://www.001lunwen. com/yuanyi/227988.html (дата обращения: 10.11.2020).

7. 广东省城乡规划设计研究院. 广州历史文化名城保 护规划, 2014. - C. 1-40.

8. 王树声. 历史文化名城格局的价值及保护传承. 2020中国建筑学会学术年会: 好设计・好营造--推动城 乡建设高质量发展. - 30.10.2020.

9. 方晓风. 清代北京宫廷宗教建筑研究. / 风方晓. - 辽宁：辽宁美术出版社, 2018.

10. 广州市规划局，广州市城市建设档案馆，广州建筑 师学会. 五羊城脉一1911-1949 广州城市建设. 广州: 广 东人民出版社, 2012. - C. 10-30.

11. 杨宏烈. 岭南骑楼建筑的文化复兴. / 宏烈杨. 北京：中国建筑工业出版社, 2010.

12. 邓兴栋，问永涛，曾壁. 广州城市总体规划的演变 与思考. [Электронный ресурс] / 栋邓兴, 涛间永, 壁曾 // 城市规划学刊. - 2017. - №3. - Режим доступа: http://www. guihuayun.com/api/app/nav_weixin_detail.php?wid=35879 (дата обращения: 10.11.2020). 
13. 陈昆仑. 自然 - 空间 - 社会：广州城市水体的人 文地理学研究. / 仓陈昆. 一武汉: 中国地质大学出版社, 2015. - C. 113-119.

14. 张春阳，颜益辉. 保护传统街巷空间特色，促进 健康城市发展一一以广州市西关为例. / 春阳张, 益辉

颜 // 城市建筑. - 2018. - №9.

15. 孙一民，张春阳，林健生，苏平，骆乐. 江门长 堤历史街区. / 一民孙, 春阳张, 健生林, 平苏, 乐骆.

- 广州: 华南理工大学出版社, 2016.

16. 冯江，谢中慧，黄丽丹. 明清广州府的 “里” . / 江 冯, 中慧谢, 丽丹黄 // 建筑遗产. - 2019. - № 2. - C. 1-11.

\section{References}

1. Guangzhou City Master Plan (1991-2010). (In Chinese)

2. He Jingtang. Architectural creation in urban renewal. China Urban Renewal Development Report 2018-2019. Beijing: China Urban Science Research Association, 2019, pp. 2-8. (In Chinese)

3. Sun Yimin. Quality construction of urban public space. China Urban Renewal and Development Report 2018-2019. Beijing: China Urban Science Research Association, 2019, pp. 21-25. (In Chinese)

4. Zhang Chunyang. Urban design thinking based on the concept of health. Healthy citylaboratory WLANLab. 2020.03.10 Accessed mode: https://mp.weixin.qq.com/s/RAFqj5oSv1bpsA2DdI1_w (Accessed 11/10/2020). (In Chinese)

5. Shevchenko E.A. Gradostroitel'nye problemy sokhraneniya istoriko-kul'turnogo resursa Rossii [The Town-Planning Problems of Conservation of the Historical and Cultural Resource of Russia]. In: Academy. Architecture and construction, 2012, no. 1. (Accessed 02/16/2021). (In Russian, abstr. in English)

6. Zhao Xiaoming. Analysis on the micro-renovation of public green space in Guangzhou's old urban area: Taking Changhua Yong as an example. First Papers Network. Accessed mode: https://www.001lunwen.com/yuanyi/227988.html (Accessed 10/30/2020). (In Chinese)

7. Guangdong Provincial Urban and Rural Planning and Design Institute. Guangzhou Historical and Cultural City Conservation Planning Manual, 2014. (In Chinese)
8. Wang Shusheng. The value and protection and inheritance of historical and cultural city patterns. 2020 China Architectural Society Annual Conference: Good Design and Good Construction - Promote the high-quality development of urban and rural construction. 30.10.2020. (In Chinese)

9. Fang Xiaofeng. Research on the religious architecture of Beijing Palace in Qing Dynasty. Liaoning: Liaoning Fine Arts Publishing House, 2018. (In Chinese)

10. Guangzhou City Planning Bureau, Guangzhou Urban Construction Archives, Guangzhou Institute of Architects. Annals of Guangzhou - The Urban Construction from 1911 to 1949, 2012, pp. 1-40. (In Chinese)

11. Yang Honglie. The Cultural Renaissance of Lingnan Arcade Architecture. Beijing: China Construction Industry Press, 2010. (In Chinese)

12. Deng Xingdong, Yan Yongtao, Zeng Kun. Evolution and Thinking of Guangzhou City Master Plan [Elektronnyi resurs]. Urban Planning Journal, 2017, no. 3 http:// www.guihuayun.com/api/app/nav_weixin_detail. php?wid=35879 (Accessed 10/30/2020). (In Chinese)

13. Chen Kunlun. Nature-Space-Society: Research on Human Geography of Guangzhou Urban Water Body. Wuhan: China University of Geosciences Press, 2015. (In Chinese)

14. Zhang Chunyang, Yan Yihui. Preserving the Spatial Characteristics of Traditional Streets and Promoting the Development of Healthy City: A Case of Xiguan in Guangzhou, China. Urbanism and Architecture, 2018, no. 9. (In Chinese)

15. Sun Yimin, Zhang Chunyang, Lin Jiansheng, Su Ping, Luo Le. Changdi Historical Neighborhood in Jiangmen City. Guangzhou: South China University of Technology Press, 2016. (In Chinese and Engl.)

16. Feng Jiang, XieZhonghui, Huang Lidan. Li, the Neighbourhood Unit in Canton Prefecture during the Ming and Qing Dynasties. In: Heritage Architecture, 2019, no. 2, pp. 1-11. (In Chinese)

Лысая Дарья Александровна (Гуанчжоу). Доктор инженерной архитектуры. Постдокторант Архитектурного факультета Южно-Китайского технологического университета (510640, КНР, Гуандун, Гуанчжоу, р-он Тиенхэ, ул. Вушан, 381). Эл.почта: daria.lisaya@gmail.com.

Чжан Чунян (Гуанчжоу). Доктор инженерной архитектуры. Профессор архитектуры и городского планирования Архитектурного факультета Южно-Китайского технологического университета (510640, КНР, Гуандун, Гуанчжоу, р-он Тиенхэ, ул. Вушан, 381).

Lisaia Daria (Guangzhou). Doctor of Engineering Architecture. Postdoctoral researcher in the School of Architecture, South China University of Technology (510640, Tianhe, 381 Wushan Road, Guangzhou, Guangdong, China). E-mail: daria.lisaya@gmail.com.

Zhang Chunyang, Doctor of Engineering Architecture. Professor of Architecture in the School of Architecture, South China University of Technology, Guangzhou, China. 